\title{
FLIPPING ACROSS THE OCEAN: NOSTALGIA, MATCHMAKING AND DISPLACEMENT IN FILIPINO AMERICAN NARRATIVE
}

\author{
Begoña Simal González. Universidade da Coruña
}

\begin{abstract}
The article addresses the nomadic nature of Filipino American social reality and how that is conveyed through a literature imbued with a peculiarly Filipino "exilic sensibility". The literary texts chosen to illustrate this hypothesis are Bienvenido Santos's What The Hell For You Left Your Heart In San Francisco (1987), as well as several short stories: N.V.M. González's "The Tomato Game" (1993), Bienvenido Santos's "Immigration Blues" (1979), Linda Ty-Casper's "Hills, Sky, Longing" (1990), and Jessica Hagedorn's “The Blossoming of Bong Bong" (1990). The fiction of Bienvenido Santos, N.V.M. González, and Ty-Casper, portray the nostalgia for an idealized homeland, especially through the oldtimers' and old people's perspective. Both Santos and González also tackle the question of green-card marriages between young Filipinas and oldtimers. On the other hand, Hagedorn's story and Santos's novel choose a young immigrant as the focal point who does not echo the elders' feeling of homesickness, displacement and exile.
\end{abstract}

If the statement that we are living in a diasporic world is taken to be true, then the Filipino American community is one of the most paradigmatic examples of that condition. In the last century, Filipinos and Filipinas have been Spanish, American and Pilipin@s. Therefore, their legal status in America has dramatically changed in a matter of years, and the Filipino American community has travelled from an incipient symbiosis with their colonizers/hosts to the realization that a new identity had to be forged in an urgently needed literature of "selfappraisal" (González \& Campomanes, 1997: 72; see Campomanes, 1992: 50-51, 72).

We have recently commemorated the Spanish loss of the Philippines, our last colonies in the Pacific, and the American take-over of the islands. Pushed by the bad economic situation in the Philippines, on the one hand, and pulled by the alluring promise of the American Dream ${ }^{1}$, on the other hand, many young "Pinoys" left for the sugar plantations in Hawaii, the fisheries in Alaska and the North West, and the fertile Californian valleys, with their burgeoning agriculture. The increasing of Filipino emigration to America was made possible by their new status as "American nationals," to which no quotas or other restrictions applied.

However, the American patronizing attitude towards Filipino people in the archipelago turned into outright contempt and exploitation at home, in the United States. The Japanese${ }^{1}$ See Takaki, 1989: 59-62 on the hardships at home and the hope of coming back "triumphantly as successful migrants, as balikbayans and Hawaiianos" (60). 
American historian Ronald Takaki illustrates the discrimination of these "little brown brothers" ${ }^{2}$ by quoting a 1930 interview to the secretary of an American agricultural organization: "It must be realized that the Filipino is just the same as the manure that we put on the land - just the same" (1989: 324). The strong Filipino presence in the subsequent Californian labour movement was a clear reaction against these racist attitudes as well as a plea for the improvement of their working conditions.

The Filipino contingent of immigrants had been very useful to the West Coast fisheries and agriculture just after the Immigration Act of 1924, which had dramatically reduced the number of legal Mexican migrants, the main cheap labour force at the time. It had gradually become less essential and even redundant, but the only legal way to stop Filipino migration was to change their status as American nationals and grant independence to the Philippines. Thus in 1934 the Tydings-McDuffie Act was passed, the Philippine Islands became a "commonwealth" for ten years, until their final independence, and quotas could eventually be placed on immigration from the archipelago (Takaki, 1989: 331-3).

It was only after the Second World War that the Filipinos who had fought against the Japanese, side by side with American GIs, were granted special privileges as war veterans. Many of these ex-soldiers were finally able to become full-fledged citizens, find a job and a niche in a more welcoming society, and eventually create new families in the United States, an accomplishment far less frequent in the old Pinoys' bachelor society (see Takaki , 1989: 362 and Chan, 1991: 140).

In 1965, a new Act was passed that liberalized immigration to an extent never before encountered in American history. As a consequence, hitherto marginalized communities such as the Asian American ones increased in numbers, and the Filipino American community registered the highest growth of all. Nowadays only one in four Filipino Americans is American-born, most come from an urban environment and don't travel as mere sojourners, but want to stay in the U.S. There are many more women than men among the new immigrants, and a constant flow of professionals and intellectuals can also be noticed, a "brain drain" caused both by the authoritarian political regime of Ferdinand Marcos (1972-1986) and by the American promise of better professional prospects than those they find in their homeland (see Takaki, 1989: 5-6, 432-434; Chan, 1991: 148-150).

The "peculiarities" of Filipino-American history have bestowed on that community several features that find an expression in their literature. The first and most pervasive characteristic is the diasporic nostalgia of an idealized homeland, and the second is the phenomenon of what we can call "the wandering Filipina".

When Filipino immigrants arrived in the United States, they had an obvious advantage over any other Asian: they could speak the language, and not only that, but, from the beginning of this century, they had been exposed to a thorough Americanizing policy that included learning English, American History and the Constitution, and, even, as some immigrant recalls, singing to the American flag, 'The Star Spangled Banner' (Takaki, 1989: 57). Edward Mattos, evoking the famous line by Kipling, maintained in that watershed year, 1965, that the Filipino was very fortunate in standing "at that remarkable junction between East and West, at that place

\footnotetext{
2 The next word used to describe Filipin@s was "flips". "Flip" can mean "flipping little island people", but it has also been used as a clearly pejorative term for Filipino people in America (then the first letter stands for "fucking"), reminiscent of other "ethnic slurs" such as "Jap" or "Chink". However, just as Chinaman, though derogatory in origin, was adopted by Chinese Americans as an "empowering word of identity", many young Pilipino-Americans have tried to appropriate the term.
}

Odisea, $n^{0} 1,2001$ 
where the twain would never meet" (1, qtd. in González \& Campomanes, 1997: 64-5). And, true enough, the Filipino liminal position has resulted in a rich syncretic culture ${ }^{3}$.

However, none of the advantages of Americanization could erase the distinctive AsianIndonesian complexion, or the indigenous cultural substratum that had survived the two main colonizations (Spanish and American) and the Japanese invasion. Cecilia Manguerra Brainard, a contemporary writer, describes the realization not only of her Filipino heritage, but also of her hybrid identity in America:

I was born and raised in the Philippines, where heavy Western influence made me believe I was Americanized. After immigrating to the U.S. as a UCLA graduate student, I quickly discovered how very Filipino I was. Two decades and several visits to the Philippines later made me realize that I have been transformed into another creature altogether - a Filipino American. (Watanabe and Bruchac, 1990: 62)

Therefore, Cecilia does not consider herself a Filipina in exile or in the diaspora, but a member of a new community, an American ethnic minority. When we speak of "immigration" and "diaspora," we are using two different concepts. I will be using these terms according to Lim's definitions in her homonymous article. It must be noted in advance that her reference to Said's theory of "filiation" and "affiliation" could be further enhanced by showing it to be parallel to Werner Sollors' exploration of consent/descent dialectics in the creation of American identity:

Immigration, which is the condition of being outside the natal order, has usually been constructed in assimilative narratives as proceeding toward integration into the "ideas, the values and the systematic totalizing world-view validated" by an affiliative order (Said 1986, 616). When the relationship between affiliative identity (socialized self) and filiative place (homeland) is reified, the resulting condensation of signification underlines national canonical categories and, arguably, also produces the conditions of exile and diaspora. The exilic experience, like that of immigration, is the condition of voluntary or involuntary separation form one's place of birth; but, unlike immigration, this physical separation is offset by continued bonds to the lost homeland, together with nonintegration into the affiliative order in which the exilic subject is contingently placed. (1997: 296)

According to this taxonomic theory, then, most of the Filipino writers I will be dealing with can be (and are) considered both diasporic Filipino writers and Filipino-American. If they are understood as Filipino exiles and emigrants, they will be included in the postcolonial phenomenon of Filipino literature written in English, with a long tradition in the islands. In the second case, Filipino-American writers could be regarded and studied as an "internal colony" just as the Chicano and Native American communities, since, according to Stephen Sumida, they create "literature in an American culture that "colonizes" Asian Americans within America's own borders" (282). Therefore, for the Filipino immigrant in the States, once the American Dream has turned into the drudge of waking life, a new vision arises, that of an

\footnotetext{
${ }^{3}$ What is not usually emphasized is the important role of the Spanish colonization - especially through the agency of the Catholic Church, overwhelmingly represented by the friars - in paving the way to that westernizing policy.
} 
idyllic archipelago far away, on the other side of the ocean, where nature and harmony can still be found, but which remains nonetheless a new unattainable dream.

Filipino writers have been "migrant souls" since the times of the self-exiled José García Villa and the permanently homeless Carlos Bulosan, who could only find emplacement in his heart. Already in 1924, Paz Márquez Benítez published a short story about the Filipino immigrant's nostalgic, even regretful, look to the lost innocence of the pristine world of the islands (Cheung, 1997: 265).

The longing and remembrance of the homeland is very much present in the older generation of Filipino American writers, especially Bienvenido Santos and N.V.M. González. These writers portray a peculiar feeling of nostalgia, that is, they "chart and repossess a fictive "homeland" or an imagined Philippines for moorings in their exilic writings and peripatetic journeys" (González \& Campomanes, 1997: 63). Bienvenido N. Santos's What The Hell For You Left Your Heart In San Francisco provides us with a poignant example of the Filipino American's "exilic sensibility" (Campomanes, 1992: 51). At one point, Augusto Tablizo, an old Filipino who has never forgotten his homeland is said to have died of a "broken heart", or so it seems, there being no other apparent reason:

One morning the old man failed to wake up. He had died in his sleep. Just like that. There was nothing wrong with him.

The couple's circle of close friends, among them the Sottos, were deeply affected by the old man's death. They were disturbed by the way he died - it seemed, for no reason.

As if I were the wiser one, I told Dr. Sotto, "The old man died of a broken heart, doctor."

"Nobody dies of a broken heart."

"Filipinos do." (Santos, 1987: 166)

That yearning also underlies the literature produced by younger generations, from Jessica Hagedorn and Ninotchka Rosca to Cecilia Manguerra Brainard and Linda Ty-Casper. Traditional or experimental, iconoclastic or classical, young and old writers alike share a nostalgic mood when their characters recall the Philippines where they spent their childhood and/or youth.

Ty-Casper's "Hills, Sky, Longing" explicitly includes this nostalgia in the very title of the story. In it, Rosalie, an old Filipino-American woman who is going through a personal crisis, looks for an anchor to her soul in the now distant lands that she had left when young. Overwhelmed by a sense of uprootedness, she drives to Half Moon Bay and gazes at the fine line of the sea horizon, wondering "[w]here on the Philippine shoreline she [would] land if she could swim directly across" (223). She then reflects on the loss and pain that life entails (225), but in her case loss takes the very specific form of cultural displacement. Even names are not the same in the new land: John was simply "Juanito back in the Philippines" (226). Thus identity is shaken and destabilised, and Rosalie is overwhelmed with a certain feeling of betrayal, especially when she realises she is the last barren link in a cultural chain that does not and cannot reach her daughters. She can glimpse the void she is leaving behind and she realizes that Honolulu had been her "port of disappearance", rather than her "port of entry" (230). She gradually comes to know that nobody will ever dream and remember life "back there":

Why did she not speak to them (her children) in their mother's songs or tell them of her father's porch, of their garden where the moon grew large then small over the 
ginger plants with soft petals wet with fragrance? When did it start to matter? ... [And h]ow long does memory matter? (225-6)

And although Rosalie resists that oblivion, that obliteration, the story ends in a pessimistic key, hinting again that this cultural displacement is the ghost that haunts her, the speck that hinders her sight and her peace, "a peregrine flying without wings" (231).

In Jessica Hagedorn's "The Blossoming of Bong Bong," we witness another gradual process of obliteration and psychological disintegration. Bong Bong's parents send him to New York in the hope that he will study or find a job there. At first Bong Bong pretends that he is attending a Business School, while he is really wandering aimlessly through the most dubious streets of the city. Little by little his hallucinating visions take the better of him until he finally forgets who he is, in a literal (192) and figurative sense. He has lost all sense of reality and lacks the most basic anchoring points: he is alone, having lost friends and family. Cultureless and rootless, nothing attaches Bong Bong to the soil, so in the end he just levitates, floating in an unreal limbo.

The nostalgia for the lost life of an idealized home back in the Philippines also pervades the fiction of Bienvenido Santos and N.V.M. González. Both Santos and González also deal with the very real plight of the "wandering Filipina" in "Immigration Blues" (Hagedorn, 1993: 422-439) and "The Tomato Game" (González, 1993: 159-165). However, though the social problem of the visa marriages is their main focus, in both stories we come upon the same nostalgic tone we had encountered in Ty-Casper.

The "o.t.'s"4 in "Immigration Blues" are shown to miss their homeland to the point of keeping all kinds of mementoes in their houses (Santos, 1979: 423). And, in a subterfuge similar to Rosalie's, even just listening to the waves bring them back to the beloved islands: "The breakers have a nice sound like at home in the Philippines. We lived near the sea. Across that water is the Philippines, I always say Seniang, we're not far from home" (Santos, 1979: 427).

The new immigrants, in this case young Filipinas, don't seem so enthusiastic about the focus of this nostalgia. Neither of them wants to go back to the islands. Many of these new arrivals explicitly want to "make it" in America (Santos, 1979: 422). In any case the first step in order to stay in the United States is getting a green card. Monica, the newly arrived immigrant in González's story, still has some Catholic qualms at marrying an old Pinoy she does not even know, but whose papers make him American, whereby she can stay in the country for as long as she wants to. On the other hand, even though she is only talked about, never present, the narrator makes it clear that Alice, the bride in "The Tomato Game", is just interested in the visa. Whereas in the first story the mediator who negotiates the deal between the girl and the old man is an acquaintance, in this story the go-between is a professional, who earns his living by making matches such as this: "Sophio Arimuhanan, Attorney-at-Law, Importer-Exporter (parenthetically) of Brides - and, double parenthesis please, of brides who cuckolded their husbands right from the start" (González, 1993: 161). Not only is Alice bringing along her lover, "Tony-boy", but she and the lawyer have even persuaded her husband-to-be to pay for Tony's education in the States.

Both lolos are duped, but whereas the old man in González's story makes "a poor job of gathering the harvest" (163), Alipio in "Immigration Blues" is not new to the "Filipina bride"

\footnotetext{
${ }^{4}$ This stands for "oldtimers" or first-generation immigrants. In the case of Filipino Americans, they are also called Pinoys, as we have already seen, and "manong", from the Spanish word "hermano", meaning "brother", and its Mexican abbreviations "mano" and "manito".
} 
system and seems to be better off in the end. Alipio is an old limping widower who needs company and looks for it in the young woman who has just arrived from the Philippines. Not only do Alipio's physical signs hint at the absurdity of the match between the frail, unsophisticated old man and the young, pretty woman, Monica; even the room suggests that Alipio has very little life left in him: "The little fish swimming about in the lighted water [of the aquarium] seemed to be the only sign of life in the room where everything was old, including, no doubt, the magazines and tabloids scattered just about everywhere" (Santos, 1971: 425).

Mrs Zafra, Monica's sister, perpetuates the green card marriage agreement she herself had "indulged in" some years before. She obviously wants to match Monica with old Alipio, whom she knows to be reasonably well off. An attentive reader can confirm his middle class status in his perfect denture, the TV set, the aquarium, the long list of canned food, although his most alluring possession are the American citizenship papers he had got as Second World War veteran (427).

Even though the retired man is obviously interested in Monica from the beginning, at first she speaks little and looks frightened, "her face in anguish, as if near to tears" (426), feeling ambushed and wanting to get out of that house: "Her skin was transparent and the veins showed on the back of her hands like trapped eels" (427). On several occasions she tries to ingratiate herself with her prospective husband by picking up his crumbs, agreeing with him on his food habits, confirming that she is as thin as his late wife and proving herself serviceable enough to volunteer in washing up. When Monica is at last hinting at the convenience of assuaging the old-timer's loneliness, she draws to a sudden stop, to her sister's astonishment and anger: "What happened, you were going great, what suddenly hit you that you had to stop, give up, defeated, her eyes were asking and Monica shook her head in a gesture that quite clearly said, no, I can't do it, I can't anymore, I give up" (437).

When Mrs Zafra eventually discloses the reasons why she and her sister are there, Alipio is not angry, but actually likes the prospect of marrying the attractive girl:

They had been talking for hours. It was visas right from the start. Marriages. The long years and the o.t.'s. Now it was visas again. ... He could see this woman very plainly, sobbing on the table. She was in great trouble. Visas. Oh, oh! Now he knew what it was all about. His gleaming dentures showed a half smile...

He wanted to say, talk of lighting striking same fellow twice, but thought better of it. A bad thing to say. Seniang was not lightning. At times only. Mostly his fault. And this girl Moni? Nice name also. How can she be lightning? (437-8).

Even though all characters seem open about the somehow unethical transaction, the narrator hints at the corruption behind this seemingly cordial agreement. Mrs Zafra leaves for the grocery store just as the traitor, Pilate, not waiting for an answer (439). The doubts arise as to who is the person betrayed, Monica or Alipio. It is he who seems most innocent, since both women sought a legal benefit through "selling" Monica as a wife. However, the last paragraphs conjure up a suggestive image that tells of Alipio's increasing sexual interest in the young woman, even though he resorts to self-delusion - in an ironic free indirect speech - in order not to feel too guilty about it: "... he was not looking at the foodstuff in the paper bags Monica was carrying. His eyes were on her legs, in the direction she was taking. She knew where the kitchen was, of course. He just wanted to be sure she wouldn't lose her way. Sometimes he went to the bedroom by mistake. Lotsa things happen to men of his age" (439). All three are sadly involved in a common social arrangement which momentarily solves the problems that are beyond them.

Odisea, $n^{0} 1,2001$ 
However, it is Bienvenido Santos's What The Hell For You Left Your Heart In San Francisco (1987) which, paradoxically through the eyes of a young immigrant, best portrays the oldtimers' plight. This novel offers a new perspective on the nostalgia of the old generation: that of David Dante Tolosa, a young Filipino immigrant. David explores the Filipino community in San Francisco, and focuses on the affluent Sottos' household, Professor Jaime's family, and the - mostly anonymous - oldtimers. It is precisely these oldtimers, and especially the only two old Filipinos who are given a name, Tingting and Augusto, who prove the most highly instrumental in the protagonist's self-discovery. Old Tingting's "confession" unveils not only the oldtimers' reason for their emigration, but also David's. Filipinos seem to be running away from something or somebody, and, in the case of both Tingting and David, this somebody is a woman, or rather, her ghost: "I'm the long-distance runner, remember? So I run. I'm still running and there's no end to this, so help me God" (Santos, 1987: 127).

David, just like Tingting, is always walking, travelling, moving around, but with "no sense of direction": "It mattered little whether I was going north or south, east or west. I was going nowhere and yet I wanted to be somewhere but I didn't know where. All I wanted was the movement..." (27). ${ }^{5}$ Like Bong Bong in Hagedorn's homonymous story, the protagonist seems to be levitating, no roots linking him to the "solid ground" of reality, of the American land: "At times ... I felt like I was floating in a vacuum, and I had nothing that my fingertips could touch, no solid ground on which to stand" (28). David lives in a constant struggle between the enticement of freedom loneliness brings and the sadness of an uprooted existence, the quintessential Filipino quagmire: "What was I doing away from my native land at a time of turmoil, how long was I going to fool myself into believing that I was happier here because I felt free? Did I really want this kind of aimless freedom? Who wants to be alone among other lost souls?" (76). David's aimless walks around San Francisco temporarily push aside his disorientation, but at times he acknowledges feeling "homesick and alone" (28). Paradoxically, it is by looking at those other lonely men, Filipino oldtimers, that David realizes his own homelessness.

It is clear what "home" means for those old Filipino Americans: their long sojourn in the States has not diminished their homesickness. The oldtimers wish to go back home, dead or alive, and both travel agencies and funeral business capitalize on this desire $(24,48)$. Evidence for the oldtimers' nostalgia for their homeland abounds throughout the novel. For instance, hopefully romantic and homesick old Filipinos can't help crying when listening to Filipino songs at the barbershop, on whose walls the picture of the most paradigmatic Filipino hero, Jose Rizal, hangs $(151)^{6}$.

Augusto Tablizo is the embodiment of the "sentimental nature" David claims for himself and his fellow countrymen. The Tablizos are a typical immigrant broken family, who have left the old generation behind, because the latter did not want to abandon the islands. One of the old parents, Augusto, clings to his home in the Philippines even after his wife has died, leaving

\footnotetext{
${ }^{5}$ His constant and brief sexual affairs or "amazing lays", as he calls them, belong to that same need of never stopping and settling in one single place or relationship. His relationships with women in America can also be read in the light of the theory of "postcolonial feminizing and eroticism" that Sheng-mei Ma develops in Immigrant Subjectivities in Asian American and Asian Diaspora Literatures (see works cited).

${ }^{6}$ Middle-aged Professor Jaime and David himself get sentimental at the end of the unexpected student production, when the Filipino national anthem, Bayan Ko, or "My Country" is sung (Santos, 1987: 176). Not only do we find homesickness among both oldtimers and recent immigrants, we also find "languagesickness", in the "flowery speech in Pilipino" that a middle-aged Filipino gives in a meeting about Federal grants for young Filipino college students (Santos, 1987: 114).
}

Odisea, $n^{0} 1,2001$ 
him alone. America and his son's house can never become his home, which remains in "a little town in Luzon named Alcala" (155). In the modern house in California, Augusto feels "like a guest, an intruder" (159), lost in his son's frequent weekend parties, and, by extension, in the American society. His sense of displacement increases when he realizes the chasm that separates him from the American-born generation: his granddaughter Karen.

Eventually, Augusto attains a good level of communication and mutual understanding with Karen. However, the old man's nostalgia finally wins the battle against his obvious love for his family, and once again he expresses his wish to go back "home":

"Yes, I do miss Alcala."

"Because of Lola?"

"That, too. But mainly because I love the place. My roots are there. That's where I

want to die. Believe me, Karen, I want to go home already."

"But Dad says you're gonna be alone there."

"How could I be alone there? That's where I belong." (165)

It is when we hear an accurate echo of old Augusto's words in the narrator's mouth that we realize David is no different from the oldtimers: "Where would be my next stop? The pity of it was that, which ever way I turned, it wouldn't be towards home and that's where I knew I truly belonged" (179). Gradually, then, David and we readers become aware of the cultural displacement the protagonist is suffering in his beloved San Francisco, of his painful exile and rootlessness, and, above all, of the strong feeling of homesickness he shares with the oldtimers: "What the hell was I doing in San Francisco? Then it dawned on me that I probably looked like them [the oldtimers] now, much younger but just as ragged and lost... I had somehow blended with the scene, become one of the faceless crowds..." (87).

Even a stranger, the woman who conducts the poetry workshop in the library, notices that David looks like "an orphan," helpless and lost, in need of an anchor which for a while is provided by the magazine project. Consequently, the mirage of anchorage and emplacement vanishes with the project and David comes face to face to an unbearable feeling of being adrift:

I had just been told to stop dreaming of ever putting out the magazine I had been working on all these months. It meant the end of a lot of things that had begun to take shape in my mind, things that had become part of my life. This was rejection of the bitterest kind for a writer like me, looking for an anchor to hold on to - and yet I felt nothing. (180)

David's symbolic encounter with his long-lost father at the end of the novel is not only a reconciliation with his own roots, but is also a recognition of that father in all the oldtimers he has met in San Francisco. Finally, their common feeling of homesickness has brought David and the old generation together: "It was the way of the exile, a never-ending quest for common roots, similar beginnings. Our nostalgia took on the same shape, the same boundaries, the same hues and smells, sensations, real or imagined deprivations, hurts and grudges, little victories we had not shared with anyone else, a continuing hope for the future in a faraway land" (125). In his final good-bye to the city and Estela, just after the magazine project comes to an end, David significantly hails "the nameless ones" and acknowledges their common dreams and anxieties: 
There is fear in our hearts as we listen for tremors under our feet and against our will we look back to that home faraway now lost in the late mists of evening and the long years. Pray that life gives us another chance for each loss we suffer as we walk and live on these sullen streets among rusting wharves, smelly canneries and loud fish markets far from the vineyards spilling with bubbly wine.

Dear Estela, good night. (192; emphasis added)

The Filipino American authors we have been analyzing not only depict the moral plight of many Filipinas seeking green-card marriages, the loneliness of Filipino old-timers and the disorientation of young Filipinos. Their novels and short stories portray the very nomadic life of Filipino (American) people and the evasive and fluid nature of their identities, thereby developing what is indeed the most prominent feature of Filipino American literature according to many critics, Filipino "(non)identity" (see Campomanes, 1992: 50-4). These narrative feats show us that exile and confusion through lolos who bear witness to a life travelling from campo to campo, young Filipinas who consent to arranged marriages in order to flee an impoverished postcolonial country, displaced men and women who cannot find a real home, their father, their roots, a site of emplacement, and try instead to levitate, fly without wings, or move without going anywhere. Thus, these Filipino-Americans illustrate both Said's "generalized condition of homelessness" and what Appadurai calls "the cultural "disjunctures" characteristic of latetwentieth-century population transfers" (González and Campomanes, 1997: 63). Whether exiled in their own human and postmodern condition or dis-membered by their migrant status, "at the very least," as González put it in the introduction to his 1993 anthology, stories such as these "can provide the gift of remembering" (xviii). Re-membering.

\section{REFERENCES}

Campomanes, O. V. 1992. "Filipinos in the United States and their literature of exile". Reading the Literatures of Asian America. Eds. S. G. Lim and A. Ling. Philadelphia: Temple University Press. 48-73.

Chan, S. 1991. Asian Americans. An Interpretive History. Boston: Twayne Publishers.

Cheung, K., ed. 1997. An Interethnic Companion to Asian American Literature. Ithaca: Cornell University Press.

Chin, F.; J.P. Chan; L.F. Inada and S. Wong, eds. 1974. Aiiieeeee. Washington: Howard University Press.

González, N.V.M and O. Campomanes. 1997. "Filipino American literature”. In Cheung . 62-124.

González, N.V.M. 1993. The Bread of Salt and Other Stories [1950-1990]. Seattle: University of Washington Press.

Hagedorn, J. T., ed. 1993. Charlie Chan Is Dead. An Anthology of Asian American Fiction. New York: Penguin.

. 1990. "The blossoming of Bong Bong”. In Watanabe \& Bruchac. 81-92.

Lim, S. G. 1997. "Immigration and diaspora”. In Cheung . 289-311.

Ma, S. 1998. Immigrant Subjectivities in Asian American and Asian Diaspora Literatures. New York: State University of New York Press. 
Said, E. 1979. Orientalism. New York: Vintage-Random.

Santos, B. 1979. "Immigration blues”. In Hagedorn ,1993. 422-439. 1987. What The Hell For You Left Your Heart In San Francisco. Quezon City: New Day Publishers.

Sollors, W. 1986. Beyond Ethnicity: Consent and Descent in American Culture. New York: Oxford University Press.

Sumida, S. H. 1997. "Postcolonialism, nationalism, and the emergence of Asian/Pacific American literatures". In Cheung . 274-288.

Takaki, R. 1989. Strangers from a Different Shore. Boston: Little Brown.

Ty-Casper, L. 1990. “Hills, sky, longing”. In Watanabe \& Bruchac. 222-231.

Watanabe, S. and C. Bruchac, eds. 1990. Home to Stay: Asian American Women's Fiction. New York: The Greenfield Review Press. 